\title{
Globalization, Modernization, Mastery of Reproduction of Space, Spatial Articulation and Social Change in Developmental Dynamics in Suburb Area of Makassar City (A Study Concerning on Urban Spatial Sociology)
}

\author{
Batara Surya ${ }^{1}$ \\ ${ }^{1}$ University " 45 ” of Makassar, Indonesia \\ Correspondence: Batara Surya, University "45" of Makassar, Jl.Urip Sumoharjo, km 4, Indonesia. E-mail: \\ bataraciptaperdana@yahoo.co.id
}

Received: May 25, 2014 Accepted: June 21, 2014 Online Published: July 29, 2014

doi:10.5539/ass.v10n15p261 URL: http://dx.doi.org/10.5539/ass.v10n15p261

\begin{abstract}
The study is undertaken in suburb area of Makassar City by analyzing process of globalization, modernization, mastery of reproduction of space, spatial articulation and social change in developmental dynamics in suburb area of Makassar City by applying quantitative and qualitative approaches (mixed method). Data is acquired from some sources and community informants living in suburb area of Makassar City. Mastery of reproduction of space dominated by capitalism urges social formation change when at the beginning, it was single and then it turns to multiple social formation. When new social formation is taken place, it indicates different procedures of capitalism and pre-capitalism social formation in mastery of reproduction of space which are coexisted and affected community exclusion. This condition indicates that spatial articulation in suburb area of Makassar City does not run optimally. Social change tendency taken place in this community moves toward structural form, and rationalization of action moves toward cultural form.
\end{abstract}

Keywords: globalization, modernization, reproduction of space, spatial articulation and social change

\section{Introduction}

Urbanization and modernization as a perspective gives an overview of urban dynamics process having physical, economic and urbanities mobility acceleration vertically and horizontally. The process, then, causes spatial physical change in suburb area, which associates positively to urban structural change and spatial pattern, especially in suburb areas. Globalization is comprehended as a process changing traditional condition to a new condition in form of post-modernistic or a condition where dependence and interrelationship is much dominant (Soegijoko, 2005, p. 65). This context gives an overview that globalization is a process attempting to integrate world-system as a whole, so cities development of the Third World and especially major cities in Indonesia will have interrelationship into a system.

World-system perspective through tripolarity model designates two main reasons on why world economy-capitalist system existing today needs marginal category. First, polarization of the world system and second, to assist formation of climate and new economic region. This context indicates that development of world system today will finally affect positively cities of the Third World, including major cities in Indonesia. Initial indication of major cities development in Indonesia is marked by development of strategic economic functions, so it contributes positively to rate of urbanization and suburbanization in suburb areas. Globalization has given great chance to multinational companies to spread around the world in an effort of expanding market, escalating economic scale, looking for the more competitive raw materials, and so forth (Eissenring, 2013, p. 14). Thereby, this condition is comprehended as a system proceeding over time, and it will finally become starting motor of urban development acceleration and especially for suburb areas.

Phenomenon occurred in suburb area of Makassar City is indicated as new developing area which finally makes suburbanization going on over time. This process, then, leads to very intensive land use conversion in suburb area, from agricultural land use into industrial, commercial, educational and settlement land use in a very complex space utilization intensity. Meaning that suburb area of Makassar City has gone on conversion of means 
of production into reproduction of space. The process is initiated by mastery of means of production, and then it is shifted to mastery of reproduction of space. Afterward, it will create a space where representationally motored by capitalism on behalf of constructing modernization in suburb area. The reality is similar to the thought of Lepebvre (1981: 1996), that mastery of means of production heading to reproduction of space will always be followed by production of space representationally. The process, afterward, will become starting motor of spatial physical change in suburb area of Makassar City which moves forward very fast and revolutionary. And at last, it will provoke process of urbanization and suburbanization along with their complexity.

\section{Reproduction of Space and Spatial Articulation in Suburb Area of Makassar City}

Phenomenon in suburb area of Makassar City is indicated by the existence of strategic economic functions, regardless of regional transportation route support. It also affects high urbanities mobility. Flourishing new central places in the suburb area is identified as polarization effect of central activity in Makassar City. Direct occurred polarization encourages process of morphological change in suburb area which is dominated by capitalist productive economic activity. Development of commercial functions which become dominant nowadays triggers increase of urbanization to Makassar City. Urbanization as a process is motorized by spatial and economic change, and also it is encouraged by human factors, natural resources and technology generating economic, social and physical condition which shall be dealt with by urban development policy (Knox in Soetomo, 2009, p. 43).

Space displacement in suburb area of Makassar City is characterized by land use conversion which had encouraged physical transformation. The occurrence of physical transformation causes mastery of reproduction of space dominated by capitalism in suburb area of Makassar City. Physical transformation relates to tangible humanitarian phenomenon/forms (Yunus, 2008, p. 163). In this context, it gives an overview that physical transformation in suburb area of Makassar City creates morphological change in suburb area which strengthening capitalism more to mastery of reproduction of space. It means that spatial allocation in context of suburb area development of Makassar City is greatly affected by capital ownership, whereas this capital ownership associates positively to capitalism on behalf of development modernization in suburb area of Makassar City.

Spatial articulation is comprehended as an indication arising in suburb area of Makassar City in mastering reproduction of space by capitalist in one side and pre-capitalist in the other side. These both powers are coexisting, but they are not linked to each other. Articulation concept is an "anatomical metaphor" since different procedures in modes of production are linked. Articulation focuses more in considering production structure than production exchange. Articulation approach is applied to explain a much broader concrete research, including imperialism, commodity production in the city, peasantry, uneven spatial development, and so forth (Meillaxous, 1972). Reproduction of space dominated by capitalism indicates that spatial articulation occurred in suburb area of Makassar City does not run optimally. Its tendency affects community exclusion where the community has lived in suburb area prior to developed new functions.

\section{Research Method}

Research site is in suburb area of Makassar City. It is executed in November, 2012 to August, 2013. Applied approach herein is case study. Applied data analysis method in this study is combination of quantitative-qualitative approach (mixing methods). Philosophical reason in combining these two approaches are: (1) triangulation logic; in this matter, qualitative research finding is re-checked by quantitative research, and vice versa in order to strengthen the finding validity, (2) quantitative and qualitative research are combined to give a general overview, (3) quantitative research is applied to structural characteristics of social life, and qualitative research takes subject's quality as starting point, so these two approaches is attended collectively in executing the study, (4) quantitative research is applied in analyzing relationship of inter-alterations, qualitative research is applied to assist in harmonizing factors underlying constructed relationship, (5) quantitative approach is applied to reveal structural characteristics of social life in large-scale size, while qualitative approach tends to reach behavioral in small-scale size, so researcher makes an effort to reveal these two levels, so quantitative and qualitative guides are applied collectively, and (6) in order to obtain data of the two different realities, it needs combination of the two approaches (quantitative and qualitative)

\section{Discussion}

Period of 1949 is marked by resigning of most foreign citizens and nationalization of foreign companies happened in late 1950s. There was also occurred reposition of Makassar City as provincial capital. And even, innate quality of Makassar people vanishes along with arrival of new comers from inlands who try to save their lives from riot act due to various post-revolutionary upheavals. Between periods of 1930s to 1961, population of 
Makassar City increases from around 90,000 to 400,000 people. Half of that those people are new comers from outer areas of Makassar City. It means that since 1930-1961, initial urbanization process and modernization of Makassar City occurred intensively.

Based on that historical moment, it gives an overview that development of Makassar City is started by commercial activity. This commercial activity triggers arrival of new comers to Makassar City. Entry of new comer will finally make Makassar City experiencing region enlargement by creating new cities, it is initiated by constructing settlement clusters (China, Malay, and Arab) surrounding Fort Rotterdam Fortress; today, it is known as Sombaopu area. In historical course of Makassar City, it also gives an overview that since at the beginning, formation of the city does not apart from the presence of commercial capitalism having role in changing appearance of Makassar other than factor of power influence.

Status of Makassar City in map of Mamminasata Metropolitan City concept is determined as core city against surrounding regions. This condition, then, triggers region enlargement and core economic-social activity movement of Makassar City to suburb areas, so it makes functional agglomeration to suburb area of Makassar City. The process is affirmed more by function of Makassar City as commercial and service city as well as national activity center (Pusat Kegiatan Nasional or PKN) in Eastern Indonesian Region (Kawasan Timur Indonesia or KTI)

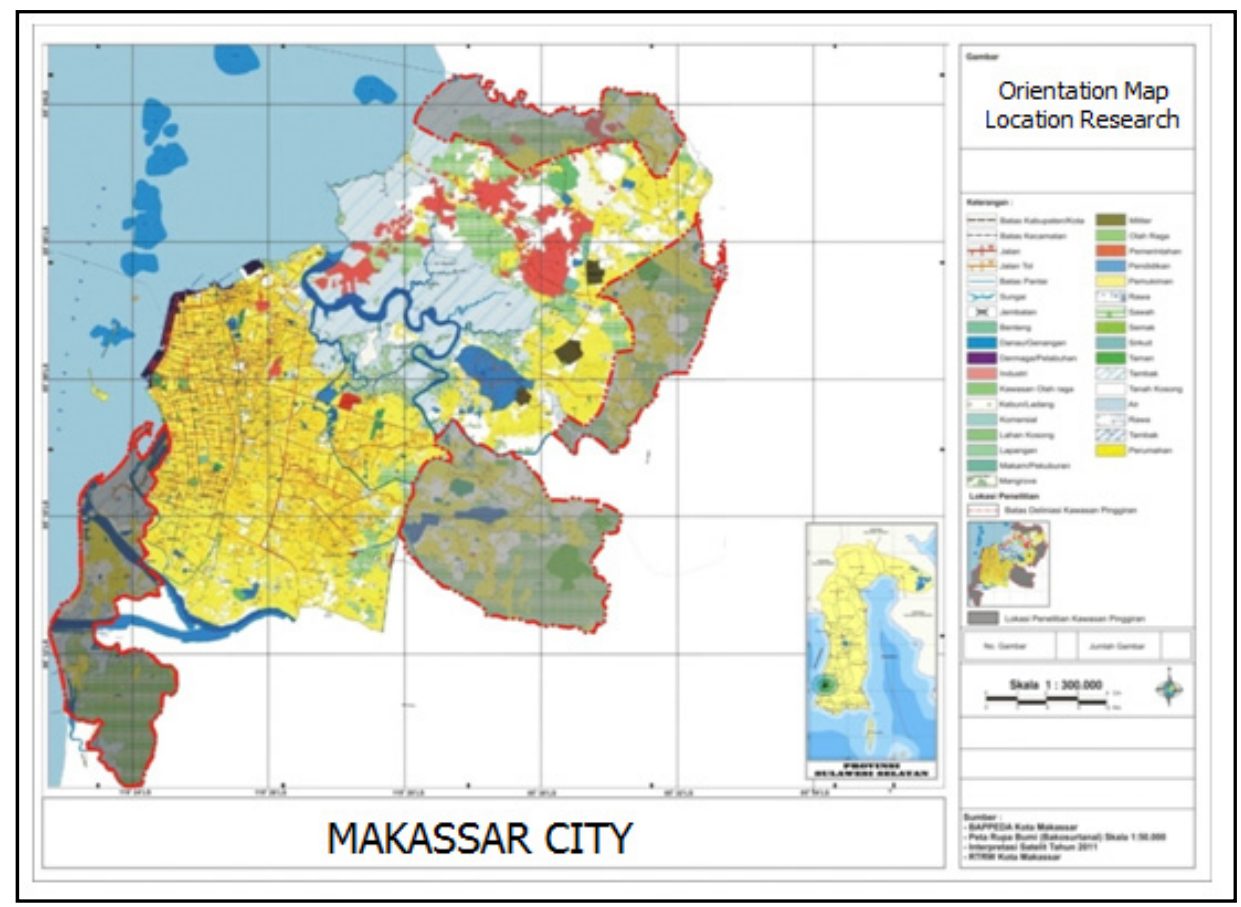

Figure 1. Suburb Area Map of Makassar City as Research Object

\section{Spatial Physical Change and Mastery of Reproduction of Space in Suburb Area of Makassar City}

Function shift of core economic-social activity of Makassar City to suburb area is, in principle, highly affected by the presence of established economic capitalist. The condition, then, causes region enlargement of Makassar City which runs in parallel with urbanities mobility to suburb area. Being observed from its process, spatial physical change in suburb area is highly affected by status of Makassar City as the core city in spatial structure of Metropolitan Mamminasata. Function shift of core city space to suburb area is assumed as effect of two affecting factors, they are (a) spatial development process in centrifugal manner, and (b) spatial development in centripetal manner (Yunus, 2008: 164). Horizontally spatial development process becomes determiner of urban area enlargement and settlement area cramming in suburb area of Makassar City. Thereby, the condition may be formulated as process of spatial enlargement occurring horizontally by inhabiting unoccupied space. This process is justified as acceleration drift factor in suburb area of Makassar City. Spatial function shift of Makassar City to suburb area is marked by land use conversion and expansion of new activity functions like function for settlement, commercial, tourism, education, health, office complex, service, and other commercial functions. 
Then, this process encourages urbanities mobility and causes social formation change of urban community in suburb area.

Core idea of spatial analysis developed by Neo Marxis pioneered by Lepebvre (1974/1971) explains that spatial practice will shift from means of production to reproduction of space stirred by capitalism.

Occurred spatial physical change and mastery of reproduction of space by capitalism increases basic needs of urban community in suburb area. Community needs hierarchy in suburb area is adapted from theoretical conceptualization developed by Maslow (Robin, 2009: 223); it consists of physiological needs, safety, self actualization, self-esteem, and social relationship. Based on the five categorizations taken through measurement process to 244 respondents in suburb area of Makassar City, description is presented in the following table.

Table 1. Relationship matrix of spatial physical change toward needs compliance of suburb community in Makassar city

\begin{tabular}{|c|c|c|c|c|c|c|}
\hline \multirow{2}{*}{\multicolumn{2}{|c|}{ Assessment Criteria }} & \multicolumn{5}{|c|}{ Needs Compliance } \\
\hline & & Physiology & Safety & $\begin{array}{c}\text { Social } \\
\text { Relationship }\end{array}$ & Self-Esteem & $\begin{array}{c}\text { Self } \\
\text { Actualization }\end{array}$ \\
\hline Highly Qualified & & 5.33 & 17.21 & 12.30 & 11.07 & 10.25 \\
\hline Qualified & & 13.11 & 28.69 & 29.92 & 21.72 & 23.36 \\
\hline Less Qualified & & 70.08 & 40.57 & 46.31 & 54.51 & 54.51 \\
\hline Unqualified & & 11.48 & 13.52 & 11.48 & 12.70 & 11.89 \\
\hline & Total & 100.00 & 100.00 & 100.00 & 100.00 & 100.00 \\
\hline
\end{tabular}

Source: Primary data, 2012

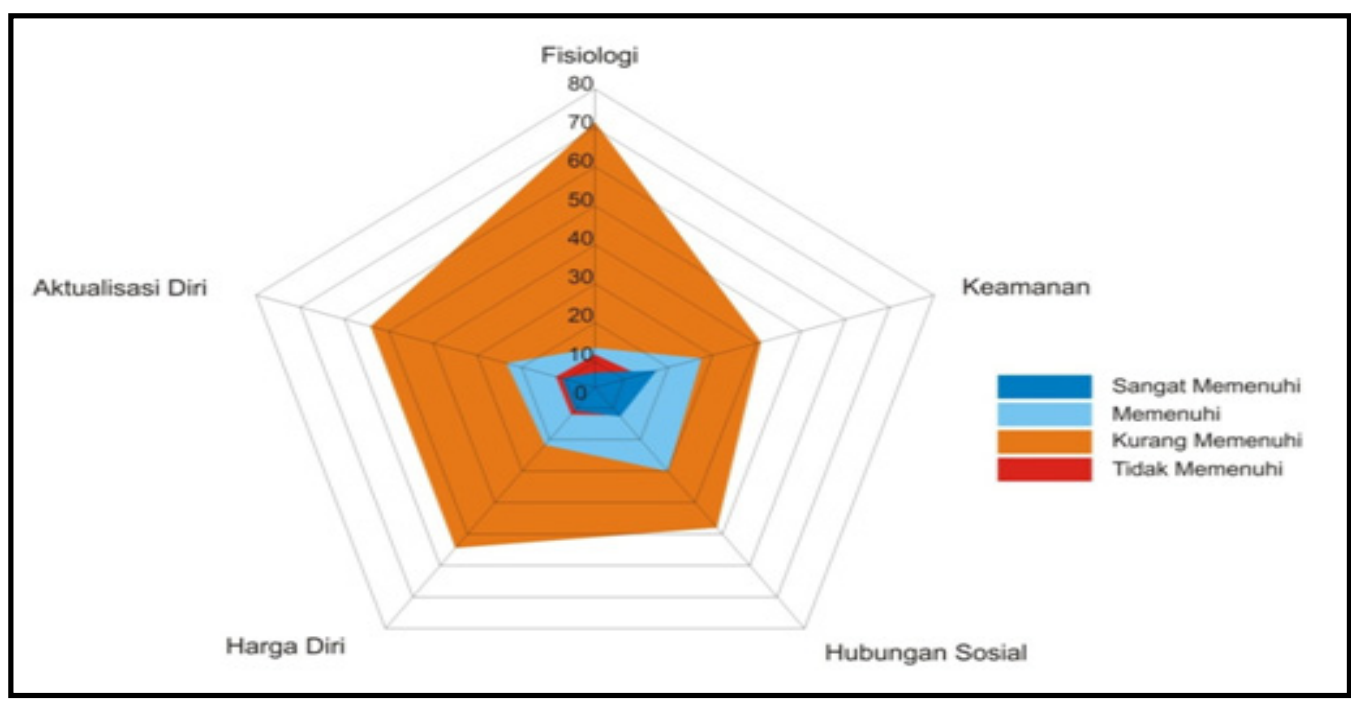

Figure 2. Relationship between Spatial Physical Change and Needs Hierarchy in Suburb Community of Makassar City, Adapted from Maslow Approach (in Robbin, 2009, p. 223)

Based on the figure above, some interpretations can be proposed. First, relationship between spatial physical change and physiological compliance of the community indicates that it is only $18.44 \%$ people are able to meet their basic needs, and the others $81.56 \%$ respondents are unable to fill the needs. Second, relationship between spatial physical change and safety compliance shows that $45.90 \%$ respondents are able to meet their safety needs, while the other $54.09 \%$ respondents declare that their safety compliance is not met. Third, occurred spatial physical change conditions the occurrence of social relationship between new comers and community. Among 244 respondents, $42.22 \%$ respondents declare that social relationship between new comers and community runs well, but the other $57.79 \%$ respondents declares the opposite condition. Fourth, occurred spatial physical change 
contributes to self-esteem compliance for local community. Among 244 respondents, it can be viewed that $32.79 \%$ respondents are proud of being urbanities through existence of developed new functions, while the other $67.21 \%$ respondents does not feel such feeling. Fifth, occurred spatial physical change also contributes to self actualization compliance in the community. From 244 respondents, $33.61 \%$ of them declare that their self actualization is met, but it does not felt by the other $66.40 \%$ respondents.

Based on the five observed aspects, occurred spatial physical change contributes positively to the existence of local community. Positive contribution is only made in social relationship between community and infiltrative new comer. While the other four aspects, spatial physical change gives weakening effect or its contribution does not have direct relationship to needs compliance in suburb community of Makassar City.

Spatial function shift in suburb area of Makassar City is identified as determinant of social formation change from single formation to multiple social formations where capitalism social formation and pre-capitalism social formation exist therein. Differences between two kinds of occurred social formation are in production organization economically and in context of mastery of reproduction of space for economic activity. Spatial articulation tends to affect community exclusion, and concerning to economic-productive activity development appeared afterward, it seems that coexistence does not have interrelation and hierarchy relationship.

\section{Spatial Articulation and Social Change of Urban Community in Suburban Area of Makassar City}

Presence of capitalist economic structure is starting motor of social change, in this case is intensity of social interaction process, is more dominant affected by job or business relation, and this interaction is supported by presence of new economic functions. Development acceleration in suburb area of Makassar City, then, grows to modernization along with its dualistic as its nature. Theoretical conceptualization of Lepebvre (Ritzer, 2008) asserts that elite space representation dominates spatial practice and representational space. Then, based on theoretical conceptualization of Soja (Ritzer, 2008), material social practice runs in line in producing and reproducing (concrete realization and urbanism specific financing). Reproduction of space by Harvey (Ritzer, 2008) explains that capitalism provokes differences of nationality, intern labor, ancient culture, gender relation, ethnic tendency, and faith. The three theoretical conceptualizations are in points of convergence if they are adopted to case of suburb area in Makassar City that spatial physical change is highly affected by presence of capitalism. The presence of capitalism encourages development of new functions and it becomes starting motor for conversion of means of production to reproduction of space, so it conditions fragmentation to local community life as indicated in differences and level of its adaptation process.

Articulation and response to the given stimulation will make stratification and status differences. It means that urban modern community is considered based on articulation capability and response to environmental changes moving forward from mechanical solidarity to organic solidarity through contractual employment as its characteristic.

Shift in community social structure from mechanical solidarity to organic solidarity causes adaptation capacity difference in the community. There are three categorizations in adaptation capacity difference in pre-capitalist and capitalist social formation as follows: (a) social adaptation process of the community indicates differences in the mastery of means of production, (b) spatial physical change, and (c) social adaptation capacity encourages the existence of community existence is highly affected by its adaptive capacity.

Penetration of dualistic capitalism and modernization in suburb area of Makassar City encourages development of formal and informal activities. This dualistic nature emerges process of social interaction either in pre-capitalist or capitalist social formation.

From the table below, social interaction relationship pattern in pre-capitalist and capitalist social formation are made based on the occurring interaction intensity after spatial physical change in suburb area of Makassar City in connection with individual business activity of community. Based on the matrix, it reveals some things as follows: first, community social relationship pattern is shown by individual interaction with the smallest social unit (family), either in pre-capitalist or capitalist social formation based on its high-categorized intensity. It means that family position still has an urgent role in social life and it becomes motivation and spirit to acquire achievement in order to reach prosperity in community.

Second, relationship with close relative in pre-capitalist social formation consists of two categories as follows: (a) in productive economic business activity of the community is one-way, while occurred tendency of interaction intensity is relatively low, (b) activity orientation as farmer and non-formal business sector activity is reciprocal and mutual. Whereas, in capitalist formation, relationship pattern of subject with close relative also has two categories as follows: (a) in activity orientation of local community working in construction projects, social 
relationship pattern of the subject with close relative is reciprocal and mutual, (b) in activity orientation of local community working in mall and capitalism economic activity centers as employee, social interaction relationship with close relative, based on its intensity, is relatively low and one-way.

Table 2. Comparison matrix of sociometry relationship in new social formation of Suburb Area, Makassar City

\begin{tabular}{|c|c|c|c|c|c|c|}
\hline \multirow{2}{*}{$\begin{array}{l}\mathrm{N} \\
\mathrm{o}\end{array}$} & \multirow[t]{2}{*}{ Social Relation Pattern } & \multicolumn{3}{|c|}{ Pre-Capitalist Social Formation } & \multicolumn{2}{|c|}{ Capitalist Social Formation } \\
\hline & & $\begin{array}{l}\text { Productive } \\
\text { Economic } \\
\text { Business }\end{array}$ & Farmer & $\begin{array}{l}\text { Informal } \\
\text { Sector }\end{array}$ & $\begin{array}{l}\text { Construction } \\
\text { Worker }\end{array}$ & $\begin{array}{l}\text { Employee } \\
\text { (Formal } \\
\text { Sector) }\end{array}$ \\
\hline 1 & 2 & 3 & 4 & 5 & 6 & 7 \\
\hline 1 & Blood Relationship (Parent and Brotherhood) & $\longrightarrow$ & & & & $\rightarrow$ \\
\hline 2 & Relationship with Close Relative & $\rightarrow$ & & & & $\rightarrow$ \\
\hline 3 & Relationship with Work or Business Relation & 4 & $\ldots \ldots$ & $\overline{4}$ & $\overline{4}$ & \\
\hline 4 & Relationship with Local Community & $\rightarrow$ & 7 & $\rightarrow$ & $\overrightarrow{4-}$ & $\rightarrow$ \\
\hline 5 & Relationship with Visitor (Individual of Outer Community) & $\rightarrow$ & $\ldots \ldots$. & $\ldots \ldots$. & $\ldots \ldots$. & $\overrightarrow{4}$ \\
\hline 6 & Relationship with Management (Job Performance Control) & $\ldots \ldots$ & ......... & $\ldots \ldots .$. & $\rightarrow$ & $\rightarrow$ \\
\hline
\end{tabular}

Source: Analysis Result, 2012

Symbol Description:

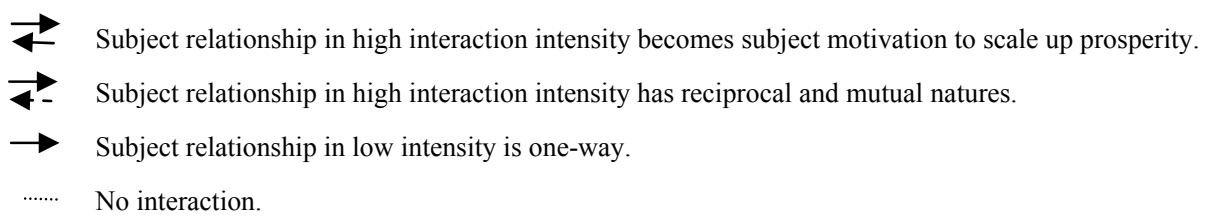

Third, social relationship pattern related to work and business relation in pre-capitalist social formation consist of two categories as follows: (a) in productive economic business activity and informal sector, based on interaction relationship intensity of the subject with work or business relation, is categorized as high, reciprocal and mutual, (b) in job orientation as farmer, social interaction tendency is not found. It means that subject activity orientation as farmer tends to have inter-individual relationship, and it aims to develop kinship relationship in the community. While, in capitalism social formation, relationship intensity with work or business relation is categorized as high and reciprocal. It means that activity orientation of the subject as construction worker and employee of mall along with other economic functions indicate work relation role which contributes positively to viability of both activities.

Fourth, social relationship pattern related to subject and community in pre-capitalist social formation have two categories as follows: (a) in productive economic business and informal sector activities, based on interaction relationship intensity of the subject with community is one-way where the relationship is relatively low, (b) in job orientation where the subject is farmer, relationship with community is reciprocal and mutual where the interaction intensity is categorized as high. It means that activity orientation whose job of the subject is farmer tends to have individual-community relationship where the intensity points to an effort to maintain community existence. Whereas, in capitalist social formation, relationship of subject with community consists of two categories, they are: (a) in subject's activity orientation as construction worker, individual interaction intensity with group is categorized as high and reciprocal, (b) in subject's activity orientation as employee in mall and commercial economic activity, interaction intensity with group is relatively low and one-way. It means that group function and role does not contribute positively to the presence of mall employee in functions of commercial economic activity.

Fifth, subject social relationship pattern with management of controlling relationship to job performance in pre-capitalist social formation, in general based on social interaction process, does not occur. Whereas, in capitalist social formation, relationship of the subject with management in term of controlling job performance occurs either in activity orientation of being construction worker and mall employee, and it also functions as commercial economic activity. 
Sixth, social relationship pattern relating to subject with individual out of the community in pre-capitalist social formation creates two categories: (a) in productive economic business and informal sector activity, based on interaction relationship intensity between subject and individual out of the community, is reciprocal in high interaction intensity, (b) in subject's job orientation as farmer, relationship with individual out of community tends to be absence. It means that subject's activity orientation as farmer tends to have relationship with individual of community member in order to maintain local community existence. Whereas, in capitalist social formation, subject relationship with community consists of two categories, they are: (a) in activity orientation where the subject works as construction worker, subject interaction with individual out of the community tends to be absence, (b) in activity orientation where the subject works as mall employee and commercial economic activity, subject's interaction intensity with individual out of the community is reciprocal. It indicates that function and role of individual out of the community, in this case are customers of mall and commercial economic functions, contribute positively to the existence of mall employee and it is one-way interaction. Thereby, social relationship in capitalism social formation has controlling nature more on activity performance as shown in relationship of inter-worker classes, and it is full control relationship.

Development of new functions in suburb area of Makassar City conditions the occurrence of spatial articulation and tends to dominating capitalist production activity. It also causes reposition of community individual position to act as worker whose powers are being exploited. Such reality completely supports theoretical conceptualization of Meillasoux ans Rey (1972) stating that condition shift from old capitalism is not the product of capitalism, but it is made from composition of pre-capitalist special modes of production and articulation through capitalism.

This articulation, then, is interpreted through class relationship. Then, moving power of capitalist economic creates a policy to promote exploitation of space, so it limits community space to utilize resources for production (nature). This condition is backed up by environmental physical engineering which emerges multiple new activities as means of urbanism activity. Finally, there will appear new town morphology where the community is motivated to adapt in situation and natural condition which had been engineered. This condition repositions individual of the community who will, finally, not have power over means of production, except for acting as labor. This condition will also become relationship of inter-classes in capitalism social formation. It means that capitalism economy needs cheap labor to be exploited.

Description on community adaptation level after spatial physical change in suburb area of Makassar City as determinant of social formation change causes the occurrence of job celling in community. There are two job celling categories in local community as indicated based on adaptation level: (a) local community working system in pre-capitalist social formation, and (b) working system in capitalist social formation. Then, shift condition "dominated by an articulation of two modes of production, in this case is capitalist modes of production and non-capitalist modes of production, shows the presence of capitalist which turns to more dominant or it will be more dominant to others. This condition will finally extend to suburb area of Makassar City and it conditions adaptation level difference in community. Afterward, it continues to job celling system, which at the beginning it is relatively homogeneous (rural agrarian) and then it turns to urban industrial and dualistic (formal and informal) as its characteristics.

\section{Conclusions}

1. Globalization as the world system contributes positively to development modernization in suburb area of Makassar City. Modernization in suburb area of Makassar City is indicated by conversion of means of production to reproduction of space motorized by capitalism in new functions development framework. Also, modernization causes spatial physical change occurred very fast and revolutionary.

2. Land use conversion is marked by conversion of means of production to reproduction of space. It indicates mastery plan in dominating reproduction of space which is coexisted between space of unrelated capitalist and pre-capitalist. Mastery of reproduction of space by capitalism affects difference in hierarchical compliance of community needs and encourages single social formation change to multiple social formations in one spatial articulation which does not run optimally, so it becomes starting motor of community social formation in suburb area of Makassar City.

3. Occurred social change causes change of social interaction and difference of community social adaptation in suburb area of Makassar City responding to environmental change. Social change tendency taken place in this suburb community of Makassar City moves toward structural form, and rationalization of action moves toward cultural form. 


\section{References}

Anonymous. (1993). Perubahan Sosial di Indonesia Tradisi, Akomodasi dan Modernisasi. Penerbit. Program Pascasarjana Universitas Padjajaran Bandung.

Anonymous. (2005). Pembangunan Kota Indonesia Dalam Abad 21 Konsep dan Pendekatan Pembangunan Perkotaan di Indonesia. Penerbit. URDI - YSS.

Attir, O. M. (1989). Sosiologi Modernisasi. Penerbit. Tiara Wacana Yogya.

Cresswell, J. W. (1997). Research Design Qualitative and Quantitative Approach. London: Sage Publication.

Eisenring, S. (2013). Percikan Ide Dan Pengalaman Empiris Menuju Sosiologi Arsitektural. Penerbit. Fahmis Pustaka

Fisher, A. (1984). Environmental Psychology. New York: Holt, Rinehart, dan Wiston.

Harvey, D. (2009). Neoliberalisme Dan Restorasi Kelas Kapitalis. Penerbit. Resist Book.

Ibrahim, L. D. (2002). Kehidupan Berorganisasi sebagai Modal Sosial Komunitas Ketetanggaan di Jakarta. Penerbit. URDI.

Lefebvre, H. (1981). La Produktion de L'espace. Edition Anthoropos.

Lefebvre, H. (1996). Writing on Cities. Blacwell Publisher.

Millassoux, C. (1972). From Reproduction to Production. Economic and Society.

Ritzer, G. (2008). Teori Sosial Postmodern (terjemahan oleh: Muhammad Taufik T. Judul asli: The Postmodern Social Theory). Penerbit. Kreasi Wacana Yogyakarta.

Ritzer, G. (2008). Teori Sosiologi: Dari Teori Sosiologi Klasik Sampai Perkembangan Mutakhir Teori Sosiologi Postmodern (terjemahan oleh: Nurhadi. Judul asli: Sociological Theory) Penerbit. Kreasi Wacana Yogyakarta.

Robbins.P. S. (2008). Prilaku Organisasi: Organizational Behavior. Penerbit Salemba Empat.

Soetomo, S. (2009). Urbanisasi Dan Morfologi: Proses Perkembangan Peradaban dan Wajah Ruang Fisiknya. Penerbit. Graha Ilmu Yogyakarta.

Surya, B. (2010). Perubahan Sosial Pada Komunitas Lokal Kawasan Metro Tanjung Bunga Kota Makassar, Laporan Hasil Penelitian Disertasi, tidak terpublikasi. Pasca Sarjana UNM.

UN - Habitat. (2005). The State of the World's Cities: Globalization and Urban Culture. Earthscan Publication Ltd. London.

Weber, M. (2007). Etika Protestan dan Semangat Kapitalisme (terjemahan oleh: Yusup Priyasudiarja. Judul asli: The Protestant Ethic and The Spirit of Capitalism) Penerbit. Jejak.

Wolf, M. (2007). Globalisasi: Jalan Menuju Kesejahteraan (terjemahan oleh: Samsuddin Berlian) Penerbit. Yayasan Obor Indonesia.

Yunus, S. H. (2005). Manajemen Kota Prespektif Spasial. Penerbit. Pustaka Pelajar.

Yunus, S. H. (2006). Megapolitan: Konsep, Problematika dan Prospek. Penerbit Pustaka Pelajar.

Yunus, S. H. (2008). Dinamika Wilayah Peri-Urban Diterminan Masa Depan Kota. Penerbit. Pustaka Pelajar.

\section{Copyrights}

Copyright for this article is retained by the author(s), with first publication rights granted to the journal.

This is an open-access article distributed under the terms and conditions of the Creative Commons Attribution license (http://creativecommons.org/licenses/by/3.0/). 